\title{
The Utility of the ALI/UNIDROIT Project on Principles and Rules of Transnational Civil Procedure
}

Janet Walker

Osgoode Hall Law School of York University, jwalker@osgoode.yorku.ca

Source Publication:

Uniform Law Review. Volume 6, Issue 4 (2001), p. 803-818.

Follow this and additional works at: https://digitalcommons.osgoode.yorku.ca/scholarly_works (c) (1) $(9)$

This work is licensed under a Creative Commons Attribution-Noncommercial-No Derivative Works 4.0 License.

\section{Recommended Citation}

Walker, Janet. "The Utility of the ALI/UNIDROIT Project on Principles and Rules of Transnational Civil Procedure." Uniform Law Review 6.4 (2001): 803-818.

This Article is brought to you for free and open access by the Faculty Scholarship at Osgoode Digital Commons. It has been accepted for inclusion in Articles \& Book Chapters by an authorized administrator of Osgoode Digital Commons. 


\title{
The Utility of the ALI I IJNIDROIT Project on Principles and Rules of Transnational Civil Procedure
}

\author{
Janet Walker
}

\section{INTRODUCTION}

Harmonization projects abound. Globalization has fostered a keen interest in finding common ground on many legal and economic fronts. And so it might seem perfectly natural that the American Law Institute and UNIDROIT would undertake the project of developing internationally acceptable procedural rules for transnational civil and commercial litigation. However, despite the growing commentary, both critical and supportive, of the progress of this enormously challenging project, and of the particular rules under consideration, not much has been said about the utility of the project.

This article steps back from the process of developing principles and rules to consider the utility of the project in light of the changing needs of modern commerce and of other related harmonization projects. It argues that the traditional approach to revitalizing national courts as a means of dispute resolution for individuals and small businesses, that of regulating jurisdiction, is fundamentally flawed, and that the success of the more promising long-term approach of promoting forum neutrality will ultimately depend on the harmonization of procedural rules. By contributing to the discussion of the utility of the project in this way, it is hoped that the importance of the project will be clearer for those who might contribute to its progress, and that possible future directions for the project might also become clearer.

\footnotetext{
Assistant Professor of Law, Osgoode Hall Law School, Toronto (Canada). The author is an International Advisor to the ALI/UNIDROIT Principles and Rules of Transnational Civil Procedure Project.
} 


\section{A. The return to national courts}

The global expansion of sophisticated multinational businesses is well underway. Western-style fast food is available within sight of the Great Wall of China and exotic goods from the East are available in small-town America; young professionals routinely take up positions in satellite offices of local firms in distant countries; and people all around the world seem to be in constant contact by e-mail.

As remarkable as the global expansion of sophisticated multinational businesses may seem, it is now being complemented, indeed rivalled, by a potentially far more significant kind of expansion that involving individuals and small businesses. Through e-commerce and generally improved communication, the uhorizontal" expansion of the economy involving large multinational firms is now being supplemented by a "vertical" expansion that will include a fuller range of participants in the global economy. 1

Critical to the success of any economy is an effective means of dispute resolution. The international commercial arbitration movement has been a mainstay of support for the first phase of horizontal global expansion that of sophisticated multinational businesses. However, the expense involved in privately financed dispute resolution is bound to keep this means of dispute resolution largely beyond the reach of those involved in this second phase.of global expansion that involving individuals and small businesses. To support the vertical integration of the global economy it will be necessary to revitalize national courts.

National courts may never be able to provide the parties with the same degree of flexibility and confidentiality as arbitral tribunals. However, features such as flexibility and confidentiality may not be as important to the dispute resolution needs of individuals and small businesses as they have been, and will continue 
to be, to the needs of large businesses. As with so many other things in the law and elsewhere, the costs and benefits of customized vs. standardized arrangements tend to make arbitration and litigation each more suitable for a different set of circumstances. For individuals and small businesses, the State sponsorship and State regulation of national courts may ultimately make litigation a more affordable, accessible and reliable means of dispute resolution than international commercial arbitration.2

\section{B. The key drawbacks of litigation}

While litigation may hold the promise of becoming a more suitable means of dispute resolution for individuals and small businesses, it has at least two major drawbacks. First, unlike arbitral awards, which, pursuant to the New York Convention, are enforceable in many countries, the judgments of national courts are considerably less capable of international enforcement. Second, unlike international commercial arbitration, which affords the parties the opportunity to establish a neutral and mutually acceptable forum for their disputes, the differences between national laws can compromise the neutrality of the dispute resolution process, and this can enable parties to make outcome-determin tive choices of fora. The role of national courts in the new global economy may depend upon the extent to which the impact of these two drawbacks can be reduced or eliminated.

\section{International enforcement of judgments}

Efforts have been made to address the first of these drawbacks the limited international recognition and enforcement of judgments through the negotiation of a multilateral judgments Convention under the auspices of the Hague Conference on Private International Law. The project was begun in response to a request by the United States in 1992, but after many preliminary reports, a proposed text and then a revised text, and numerous sessions of negotiations, plenary and 
otherwise, the future of the project now seems uncertain) A proposal has been made to narrow the scope of the project to judgments in business.-to-business disputes issued by courts chosen by the parties. This proposal may save the project by providing a small area of consensus from which to move forward in future negotiations.

Regardless of whether or how that project moves forward, the important point to note is the exter:it to which its success could depend upon addressing the second of the key drawbacks of transnational dispute resolution through litigation that was identified above: namely, that differences in national laws can compromise the neutrality of the dispute resolution process and that this can enable parties to make outcome-determinative choices of fora. The ability to manipulate the outcome of dispute resolution through the choice of forum impairs the likelihood that it will be considered fair to give international effect to the resulting judgment.

\section{Forum neutrality}

The basic principle underlying judgments enforcement in the vast majority of legal systems is the idea that it is fair to treat the parties as precluded from relitigating the merits of a dispute that have already been determined by a court of competent jurisdiction. To the extent that one party can make an outcomedeterminative choice of forum and thereby control the outcome of the litigation, it is less obvious why it is fair to treat the other party as bound by the result and precluded from re-litigating the merits of the dispute in a different forum to seek a different result.

There are two basic approaches to securing the conditions under which it is fair to treat the parties as bound by the result of .the litigation and precluded from re-litigating the merits of their dispute. The first approach regulating jurisdiction seeks to establish rules for determining which court should decide 
the matter; and then to treat the parties as bound by the result reached by that court regardless of whether a different result might be reached by a different court. The second approach

securing decisional harmony seeks to establish conditions under which it would be reasonably expected that any court deciding the case would reach the same result; and then it would be fair to treat the parties as bound by the result reached regardless of which court heard the matter.

\section{REGULATING JURISDICTION}

Historically, the most common approach to securing the conditions for the cross-border enforcement of judgments has been to regulate jurisdiction. Thus, under the prevailing rules for recognizing and enforcing foreign judgments, a judgment is generally enforceable where it has been issued by a court of competent jurisdiction, that is, a court whose competence is internationally recognized. This is sometimes described as a court with "jurisdiction in the international sense".

\section{A. · The traditional rules}

Under the traditional standards, courts have been regarded as having jurisdiction in the international. sense where they are either the agreed forum, or the defendant's home forum. The jurisdiction of the agreed forum is supported by the estoppel principle. Since the plaintiff has chosen the forum, the plaintiff cannot later complain of the result reached in that forum. Nor can the defendant resile from the choice of forum where the defendant has agreed in advance to the particular forum, or where the defendant accepts the plaintiff's choice at the time of the litigation by appearing and defending on the merits.

The estoppel principle also supports the second of these bases of jurisdiction 
the defendant's home forum. Again, since the plaintiff has chosen the forum, the plaintiff cannot later complain of the result reached in that forum. However, the estoppel principle also applies to defendants, who it is fair to regard as bound by the result reached in their home forum because they would generally be subject to suit there in any event; and, in local matters, they would not be in a position to argue that the court lacked jurisdiction. Moreover, it is thought that they should be subject generally to suit in at least one forum and, having chosen to locate themselves in a particular place, it is thought that they should not be permitted to object to being sued there solely because the plaintiff is located elsewhere.

\section{B. Innovations for federal and regional systems}

While the traditional standards for internationally recognized jurisdiction have served the international community well, they have been found to be unduly restrictive of the possible fora available to litigants. For example, the traditional jurisdictional standards. would not include a forum in the place where the events giving rise to the dispute had occurred if it was not the defendant's home court or one which the defendant had accepted. These restrictive standards have been found to be particularly problematic in situations in which routine crossborder dealings between persons have been part of a closer integration of legal systems than exists on the international plane.

For example, the founders of the United States recognized that an essential feature of their federal system would be the requirement that the courts of the several states give "full faith and credit" to the judgments of the courts of other states.4 It was then determined that it would be necessary to. ensure that the obligation to give full faith and credit was framed in a manner that was fair to defendants s and, accordingly, it was held that defendants would be regarded as bound by the judgment of the court of a state where there were "minimum. contacts" with the forum "to make it reasonable and just according to our 
traditional conception of fair play and substantial justice" for the court to assume jurisdiction over the matter.6

Similarly, it was regarded as essential to economic integration in Europe to establish a regime of judgments enforcement that included broader bases of jurisdiction than those prevailing in the international community.7 Accordingly, the member States negotiated a treaty to regulate jurisdiction, which came to be known as ·the Brussels Convention. More recently, the Supreme Court of Canada held that

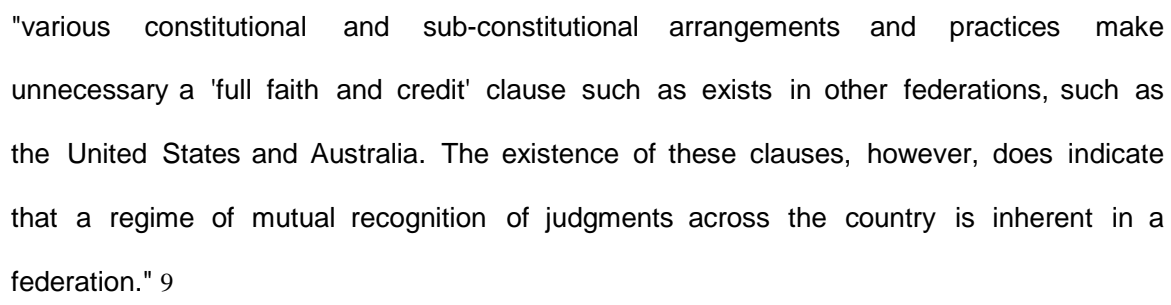

In short, broader bases of jurisdiction than those available under the traditional rules have been seen as necessary features of the dispute resolution required for closer economic integration of the sort currently existing in federal or regional systems.

\section{The limits of regulating jurisdiction}

In both the United States and Europe, it has been accepted that broader bases for jurisdiction can operate in some situations to compromise the fairness afforded to the parties. In those situations, litigants are enabled to make outcomedeterminative choices of forum.10 The resulting prejudice to the other party is tolerated, however, for the sake of facilitating the free flow of judgments within the network of legal systems. Provided that the I legal systems involved are sufficiently similar for the results not often to differ dramatically, the potential for unfairness is considered tolerable in light of the importance to the federal or regional system of the crossborder enforcement of judgments. 11

Perceiving this possibility, and regarding it as unacceptable within a federal system that promotes flexibility in jurisdiction and generous rules for enforcing 
judgments, the courts in Canada and Australia have responded by moving to harmonize choice-of-law rules so as to promote forum neutrality through decisional harrnony.12 But this is a different approach to the problem-one that will be discussed further in the next section.

However, the point worth noting here is that regulating jurisdiction is an inherently flawed approach to securing the conditions under which it is fair to treat the parties as bound by the result of the litigation. It is inherently flawed because, as the promotion of flexibility in jurisdiction within federal and regional systems demonstrates, appropriate choices of forum are ideally driven by the logistics of dispute resolution and not by the kinds of connections that are relevant to determining which law should govern the dispute. For example, even if an injured consumer happened to have moved to the manufacturer's jurisdiction and so found it convenient to sue the manufacturer there, this would not necessarily mean that she should not be entitled to rely on the standards of liability and recovery of the place where she bought and used the product and was injured by it; nor would it necessarily mean that she should be able to rely on standards other than those of the place of purchase and injury simply because she found it convenient to sue elsewhere.

Clever mechanisms for regulating jurisdiction may be developed to restrict the opportunities for outcome-determinative choices of forum 13 but, for this reason, they will always be inexact methods of achieving this end. In the absence of an appellate court with plenary jurisdiction to enunciate harmonized, forumneutral choice-of-law rules, such as exists in Canada or Australia, and in the absence of a legislature with authority to prescribe such rules for the various legal systems involved, such flaws must be tolerated for the sake of the integration of the various legal systems necessary to the federal or regional arrangement.

While the flaws inherent in this approach may be tolerated for the sake of the federal or regional integration of legal systems based on similar traditions, 
these flaws may be sufficient to prevent the regulation of jurisdiction from becoming a suitable basis for the broader international enforcement of judgments. This has been demonstrated by the history of the negotiations at The Hague for a multilateral judgments Convention. Where the participating legal systems have diverse legal traditions, and where the reasons for securing a regime are more general and diffuse than they are in a federal or regional system, it can be difficult to secure agreement on the acceptable bases for jurisdiction.

Although the negotiations began with the aspiration of establishing agreement on a range of jurisdictional bases, it now appears that the bases of jurisdiction on which agreement is possible in the near future are even narrower than those endorsed under the traditional rules discussed earlier in this article those of the agreed forum and the defendant's home forum. The least controversial of all bases of jurisdiction the agreed forum may succeed in being adopted, but only for disputes between businesses. This basis of jurisdiction, and this scope of application for it, are arguably the least controversial of all because the resolution of business-to-business disputes in fora agreed to by the parties occurs in the context of commercial risk allocation and therefore engages relatively little public concern to ensure conditions of fairness among the various possible situations.

-while the negotiations at The Hague may be successful in regard to businesstobusiness disputes in agreed fora, it does not appear that agreement will be reached on the jurisdiction of the defendant's home forum, in part because there are certain small but significant differences between the views taken on the contacts that should serve to indicate that a forum is the defendant's home forum. The obvious historical difference is that between the common law, which has used the defendant's physical presence as the. standard, and the civil law, which has used the 'defendant's domicile, but this difference has not been particularly contentious. Rather, the difference that has proved particularly 
contentious has been that of general jurisdiction in matters involving corporate defendants, and the debate. has focused on whether business activities alone should suffice to found such jurisdiction.14

\section{The utility of regulating jurisdiction}

There is much to be learned from the difficulties experienced in the negotiations at The Hague. Clearly, the second kind of global economic expansion mentioned earlier, that involving individuals and small businesses, provides a strong incentive to foster multilateral recognition of national court judgments. However, despite the strong desire to achieve the kind of harmonization necessary to permit the widespread recognition and enforcement of judgments, when this involves 'diverse legal systems, the regulation of jurisdiction represents an indirect and imprecise means that does not readily meet the requirements of fairness. In the course of these negotiations, it has become clear that differences that might have appeared at first to be minor, and therefore inconsequential, may in fact be profound and difficult to harmonize.

In particular, it has become clear that the highly remedial and progressive approach to private law that characterizes the American legal tradition is reflected directly in jurisdictional standards that cannot easily be reconciled with the approach of the majority of other legal systems whose private law traditions are more concerned with restorative justice and conflict resolution. Accordingly, while regulating jurisdiction may be a suitable foundation for a regime for the recognition and enforcement of judgments in some federal or_ regional systems, its flaws make it less suitable for others, and, so far, apparently unsuitable on the broader international plane. 
The second basic approach to securing the conditions under which it would be fair to treat the parties as bound by the result of the litigation and precluded from relitigating the merits of their dispute seeks to establish forum neutrality. This approach promotes conditions under which it would be reasonably expected that any court deciding the case would reach the same result. As with matters decided locally, the application of the estoppel principle would seem obvious because there would be no systemic basis for expecting that the outcome would vary with the forum in which the matter is decided. Within a single legal system it is expected that any court would apply the same legal rules to the same facts and produce the same result, subject only to differences that were a matter of happenstance. The challenge in establishing decisional harmony is to promote conditions under which courts in different legal systems would likewise apply the same legal rules to the same facts and eliminate any reason for expecting a different result between legal systems.

In general terms, decisional harmony is achieved between legal systems where the courts in the alternative fora could be expected to apply the same legal rules to the facts of the case. It would entail the harmonization of various kinds of legal rules: substantive legal rules, choice-of-law rules, procedural rules.

\section{A. Harmonizing substantive law}

The courts in different fora will apply the same legal rules to a given case if the substantive law in the area is harmonized, as it is between many legal systems in certain areas such as the law relating to the international sale of goods. 15 The work of harmonizing the substantive law in areas of the law that affect transnational dealings is essential to the advancement of international commerce and much is owed to institutions such as UNCITRAL and UNIDROIT for the work that is done in this area of harmonization.

However, the harmonization of substantive law is not a sufficient solution on 
its own. It must of necessity progress on a piecemeal, topic-by-topic basis and the results of harmonization projects must be adopted by legal systems one-by-one. Further, the topics that produce the most widely adopted results tend to be limited to those in which the localized remedial features of the law are relatively insignificant. Indeed, it seems increasingly clear that the harmonization of substantive law is appropriate for some areas of the law, and not for others. Thus, while this may ultimately be the most effective means of achieving forum-neutral dispute resolution, it seems unlikely that it would be sufficiently comprehensive in the foreseeable future to form the basis for the judgments of national courts to be granted widespread international acceptance, except, perhaps, within a fairly circumscribed range of disputes.

\section{Harmonizing choice-of-law rules}

The courts in different fora will also apply the same legal rules, even if the substantive law they apply is different, if the rules for determining the applicable law would lead to the same result in either forum. Even if the law is different in Country A from that in Country $B$, if the choice-of-law rules in both $A$ and $B$ would require the application of the law of Country $A$ to a particular dispute, then both courts would apply the same legal rules to the dispute.

The harmonization of choice-of-law rules has been a mainstay of the work of The Hague Conference on Private International Law for decades; 16 and it is the approach to decisional harmony that has been taken in the Australian and the Canadian federations under the direction of their highest appellate courts. As the Supreme Court of Canada explained in 1994,-

"[t]he nature of our constitutional arrangements a single country with different provinces exercisi'ng territorial legislative jurisdiction $\therefore$ would seem [...] to support a rule that is certain and that ensures that an act committed in one part of this country will be given the 
same legal effect throughout the country." 1

Where the institutional conditions exist to permit the harmonization of choice of law, it is possible to afford considerable flexibility to litigants to resolve disputes in the place that is most convenient to them from a practical standpoint, and to maintain generous standards for the enforcement of judgments, all without significant concern that the outcome of particular disputes will be affected by it and, with it, the fairness of the dispute resolution process is compromised.

\section{Harmonizing procedural law}

It would be na'lve, however, to suggest that decisional harmony could be achieved by harmonizing choice-of-law rules alone, even if all su.ch rules could be harmonized. It would be na'lve because the outcome of a dispute is often shaped by more than the substantive legal rules applied by the court. The procedure employed to resolve the dispute can have a significant impact on the way in which the relevant facts are established and the law is applied. And it is widely accepted that courts always apply their own procedural rules. Accordingly, procedural law may be aptly described as the last bastion of forum shopping.

It is interesting, almost two decades later, to revisit the colourful passage by Lord DENNING in which he described the capacity of the United States to attract litigation for reasons unrelated to the efficacy or fairness of the dispute resolution process. His Lordship said,

"As a moth is drawn to the light, so is a litigant drawn to the United States. If he can only get his case into their courts, he stands to win a fortune. At no cost to himself, and at no risk of having to pay anything to the other side. The lawyers there will conduct the case 'on spec' as we say, or on a'contingency fee' as they say." 18

Admittedly, differences in substantive law are among the factors that distort the process of forum selection and promote outcome-determinative choices. Statutory causes of actions, such as those based on regulatory laws relating to 
racketeering, antitrust and securities may not exist elsewhere, and the effects that they can have on forum selection, which have been canvassed elsewhere, 19 are beyond the scope of this article. But many of the distinctive features of civil litigation in the United States that attract litigants whose disputes .might more appropriately be determined elsewhere are procedural. These features include the widespread use of juries in civil trials, the availability of broader discovery, methods of calculating damages that lead to higher awards, and the absence of fee-shifting, or fee-shifting that is available only to plaintiffs. And the effect of these distinctive features is no less significant than it was when Lord Denning penned his famous passage.

Lest it be thought that the mischief here lies solely in the promulgation of procedural rules that are favourable to plaintiffs, and that the problem/ therefore, rests overwhelmingly with litigation in the United States, it should be noted that disparities per se are problematic in that unfamiliar procedures can operate also as a disincentive to particular choices of forum. While the distortions in forum selection that result from distinctive procedures in the United States receive publicity because they have caused litigants to select fora in the United States inappropriately, distinctive procedures in other fora that have caused litigants to avoid litigation in those fora are .also problematic. Accordingly, disparities in procedural law that inappropriately attract litigation may give rise to contentious jurisdictional disputes and resistance to the enforcement of the resulting judgments, but disparities that inappropriately discourage a choice of forum or cause resistance to it by making litigation there seem likely to be unfamiliar and hence difficult are also undesirable.

One obvious way to reduce the distortions in forum selection caused by disparities in procedure is for courts to take a very restrictive view of the matters that they characterize as procedural. This would reduce the matters to which they would insist on applying their own law, rather than a foreign governing law. In offering a critique and reformulation of the old formalistic rules for 
distinguishing matters of substance from matters of procedure, the Supreme Court of Canada recommended that Canadian courts take a functional and pragmatic approach to characterizing matters as procedural. The Supreme Court recommended that Canadian courts apply as much of the applicable law as they could in any given case and that they treat as procedural only those matters to which administrative efficacy required them to apply their own law. As long as applying the relevant foreign legal rule does not unduly impair the process of deciding the case, the courts should apply it.20

As salutary an approach as this might be, though, it is a solution that operates only on the margins and that can never effectively address disparities in core features of procedure. To the extent that procedural disparities can combine with flexibility in forum selection to affect the quality of justice, it is unlikely that the international community will embrace the free-flow of judgments. Indeed, in establishing a "full faith and credit"-like obligation within the Canadian federation, similarity of procedure $\cdot$ across the country supported the view of the Supreme Court of Canada that the

"Canadian judicial structure is so arranged that any concerns about differential quality of justice among the provinces can have no real foundation." 21

This, in turn, gave the Supreme Court confidence that there was no real prejudice suffered by permitting any Canadian court with a real and substantial connection to the matter to issue a judgment binding on the defendant throughout Canada. Where more significant' differences in procedure exist, it may be more difficult and less effective simply to encourage courts to interpret the scope of procedural law narrowly.

Accordingly, all the projects for harmonization and for rapprochement of legal systems are important to the revitalization of national courts so to enable them to provide an affordable, accessible and reliable forum for dispute resolution for individuals and small businesses in a vertically expanded global economy. 
However, among these projects, to the extent that it can assist in overcoming the final hurdle to achieving decisional harmony, the harmonization of procedural law, may ultimately hold the key.

\section{IV.POSSIBLE FUTURE DIRECTIONS FOR THE PROJECT}

In view of the special utility of the harmonization of procedural law in promoting the conditions for decisional harmony, it is possible to anticipate effective approaches that might be taken to the considerable challenges faced by the ALI/UNIDROIT project. In particular, two main challenges will be addressed in this section: those presented by differences in approaches taken to the role of civil litigation in law reform (these differences are most significant between the United States and other legal systems), and those presented by differences in approaches taken to the basic responsibilities of the participants in the dispute resolution process (these differences are most significant between the common law and the civil law).

\section{A. Civil litigat!on and law reform}

The first of these challenges arises because the extent to which the law is remedial varies considerably in certain areas of the law and in certain countries. In these areas and in these countries, the law seeks not to restore the parties' former positions so much as to respond to certain social welfare concerns that are likely to be associated with the kind of dispute being resolved. These social welfare concerns tend to vary from one legal system to another because they arise in different social welfare contexts. Further, the 'extent to which these concerns ought to be addressed in the course of civil litigation itself varies from one legal system to another. In some legal systems, such as the United States, "improving the law" is regarded as a routine feature of civil litigation, while in others, it is regarded as rendering the law impermissibly unpredictable.22 
, One example of this arises in consumer claims, in which the complaining party is likely to be an individual who has been harmed by a defective product or an inadequate service and who seeks compensation from the manufacturer or supplier of that product or service. The remedial features of the law in this area may not be restricted to the substantive rules for determining liability or damages, but may extend also to the procedure by which such disputes are resolved. Accordingly, for example, class actions and other means of aggregating claims have been endorsed in some places as an appropriate procedure to resolve such disputes. Further examples include favourable presumptions that reduce the standards of proof, such as strict liability and fraud on the market, generous pleading rules, and the availability of broad discovery, and multiple damages awards intended to provide an incentive to persons to participate in market regulation by advancing their claims.

There is some indication that the importance of securing international recognition and enforcement of United States judgments may warrant the forgoing of damages awards that are considered excessive by enforcing countries' standards.23 However, it is far from clear that such a concession to decisional harmony would extend to requiring plaintiffs to forgo the favourable elements of procedure noted above in matters involving connections to other places matters that would attract the application of foreign law to the substantive legal issues under forum-neutral choiceof-law rules.

Accordingly, there could be occasions in which conflicting commitments to the importance of the remedial potential of civil litigation and to the importance of securing legal certainty would render participant countries unwilling to harmonize the procedural rules that they regarded necessary to those commitments. This appears to have been a particularly strong source of contention in The Hague project to harmonize jurisdictional standards. As with that project, a promising response would be to reduce the proposed scope of the application of the 
ALI/UNIDROIT project on transnational civil procedure to a range of disputes unlikely to engage a determined commitment to procedures that would promote remedial benefits at the expense of legal certainty. This would not constitute an admission of defeat. While the drafters of the Convention on the International Sale of Goods could have sought to harmonize the whole of contract law, their decision to focus on the international sale of goods was a fruitful one. Similarly, in the event of such an impasse, a narrower scope might serve to secure the adoption of harmonized procedural rules in a circumscribed set of cases that could subsequently be expanded.

\section{B. Basic responsibilities of court and counsel}

The second of these challenges is that the transitional transaction costs of adopting a new procedural code are potentially overwhelming. If one of the advantages of resolving disputes in national courts is that national courts provide the security of stable procedural rules familiar to counsel, then the introduction of a new harmonized procedural code might seem counter-productive. Indeed, if there existed a popular procedural code that was readily acceptable to a wide range of legal systems, it is likely that its use would expand steadily and there would be no need to pursue efforts to draft a new set of harmonized procedural rules. However, it does not appear that such a code exists and, accordingly, the question of the transitional transaction costs mustbefaced.24

If the challenge cannot be avoided, it should nevertheless riot be overstated. The transaction costs of disparities in procedural rules are reasons for the project they are not a product of it. Reducing the transaction costs from the costs of having to deal with any one of a multitude of different procedural rules to having to deal with either local procedural rules or harmonized procedural rules is bound to be a net gain. The impetus to negotiate a multilateral judgments convention, and the analysis in this paper of the obstacles to its success that are the product of 
procedural diversity demonstrate that the time has passed when such transaction costs could be avoided by maintaining national insularity in dispute resolution.

Further, while the triumph of the United States Federal Rules has served as an inspiration to this project,25 harmonization projects of this sort in Europe 26 and those directed at the law of judgments in the United States have not yet met with the same degree of success. This suggests that in some contexts it might be preferable not to seek to replace local standards with harmonized standards, but to establish a second harmonized code for crossborder matters.27 In this regard, although the Convention on the International Sale of Goods may have had a slow start in that contract drafters in either forum. Even if the law is different in Country A from that in Country $B$, if the choice-of-law

Nevertheless, the transaction costs of. introducing a new regime may be virtually insurmountable where they relate to differences in procedure that fundamentally alter the roles of those involved in the process. At one extreme, synchronizing time limits for particular stages of the process may be achieved with very little disruption. However, at the other extreme, transferring the responsibility for establishing the factual record from the judge to the parties' counsel could necessitate such a reorientation of the basic understanding of the process as to require a virtual re-education of the legal profession in some legal systems.28 To introduce an adversarial system-based approach into a civil law legal system could require adjustments of varying significance to everything from the process of discovery to the nature of the professional obligation of confidence to the compellability of witnesses. But more than this, the differences between the systems operate at such a fundamental level of principle as to require a change in the instinctive approach taken by participants to their various roles and to their relative responsibilities to one another.

Does this make.the harmonization project ultimately infeasible? Perhaps not. To the extent that the reduction in the range and complexity of the disparities in 
procedural law is generally beneficial, it might be better to aim for a more achievable goal. Radical though the suggestion may seem, the establishment of two harmonized wocedural codes, one for each of the common law and the civil law, might be a goal that is both more attainableand more easily implemented. Such a compromise might be a disappointment to the particularly optimistic among the supporters of the project and to those who hoped soon to litigate in a world without borders, but it could serve to see the project through some serious obstacles.

\section{The utility of the Principles}

Surprisingly, it is appropriate to have left discussion of the utility of the Principles to the last. That is because in the Principles lies the promise for the future of this harmonization project.

Of all the lessons learned in the last decade through the various harmonization projects undertaken, perhaps the single most important lesson is that the establishment of a fixed cadre of harmonized rules to be imposed on national legal systems is neither the most important nor the most attainable goal.29 It has been an attractive goal for harmonization projects because it resembles the goals of domestic law reform projects and because it provides a clear framework for the project and the promise of a tidy sense of completion, but experience with this goal has been less than satisfactory. Maintaining such a goal introduces tensions into the process relating to the potential for failing to reach agreement and to the potential that the substance of any agreement reached will meet with serious resistance or will fail to be implemented uniformly.

As a result, in some of the most ambitious and significant of projects it is becoming increasingly clear thatthe way forward is to conceive of the project as 
one of progressive harmonization.30 However, the special challenge of projects involving progressive harm'onization is to find ways to implement manageable portions in manageable contexts while continuing to press forward to expand the scope of these manageable portions and contexts. It might be possible in the nottoo-distant future to implement one or both sets of civil law and common law harmonized rules. of procedure in a small number of countries for application in a relatively circumscribed range of cases. And once underway, the project could gain strength by demonstrating its utility and by undergoing further reform based on the experience gained through its operation. Building on this strength, it could be possible to increase the number of countries in which the rules were applied and to expand the range of cases to which they applied. Increased familiarity of members of the legal profession with the rules could even prompt local law reform initiatives to bring local procedures into line with the harmonized standards.

But all of this is predicated on the amenability of particular legal systems to the introduction of the Rules of Transnational Civil Procedure. What of legal systems that are so diverse that they cannot readily accommodate such a set of procedural rules? And what of legal systems that can accommodate some but not all of the procedural rules? Will they be required to choose between joining the harmonized regime and retaining features of their procedural law that they regard as essential to their justice systems? Clearly, while it is hoped that the benefits of participating in a harmonized regime would provide a strong incentive to refrain from retaining divergent practices that were not essential, it is an invidious choice to impose on a legal system.

The way forward in such legal systems is to provide clear formulations of the principles underlying the rules so that local practices can be measured against them. In some situations, there might exist alternative means to achieving the same result or promoting the same virtue. In such cases, it might be possible for a legal system in which it was regarded as necessary to retain a rule that had not been 
incorporated into the harmonized regimes to justify its retention in their procedural law by showing how it functioned in a way that was consistent with the Principles. In other cases, legal systems that were wary of having their procedural law assimilated to that of the harmonized regime might be better able to appreciate the intent of the harmonized rules through the Principles and to consider reforms that would assist in approximating their law to that of the harmonized regime in a manner that was locally acceptable.

Moreover, the benefit of the Principles would not be confined to increasing the number of countries in which the rules were applied they would be of value also to legal systems in which a harmonized regime had been adopted. The Principles could be used as an aid to judicial interpretation in securing an application of the Rules that was consistent with their objectives. Further, as clear statements of the underlying objectives of the Ru/es, the Principles could provide a reference point for reform of the Rules based on experience with the way in which the Ru/es operated in practice. In this way, the Principles, if stated in a sufficiently broad and open-textured fashion, could continue to provide leadership in the ongoing process of harmonizing procedural law. 


\section{Notes}

1 WALKER, "Beyond Big Business: Contests between Jurisdictions in a Vertically Integrated Global Economy• in: Law Society of Upper Canada, Civil Litigation Forum, LSUC (Toronto) 2000.

2 WALKER, "International Dispute Resolution in the $21^{51}$ Century: The Role of National Courts" in: Canadian Council on International Law, Looking Ahead: International Law in the $21^{51}$ Century, Kluwer (The Hague) 2001.

3 Hague Conference on Private International Law, Permanent Bureau, Preliminary Document 16: Some Reflections on the Present States of Negotiations on the Judgments Project in the Context of the Future Work Programme of the Conference (February 2002), available on www.hcch.net/e/workprog/jdgm.html.

4 United States Constitution, Article IV.1. The full faith and credit requirement was also adopted

by the drafters of the Australian Constitution and is found "in section 118 .

5 And thereby consistent with the due process requirements of either the Fifth or the Fourteenth Amendments.

6 International Shoe Co v. Washington, 326 us 310 (1945).

7 As reflected in Article 220 of the Treaty Establishing the European Economic Community, 1957.

8 The Brussels Convention of 1968 is now "Council Regulation (EC) No. 44/2001 of 22 December 2000 on Jurisdiction and the Recognition and Enforcement of Judgments in Civil and Commercial Matters", Official Journal of the European Communities L 12, 16/01/2001, 1.

9 Morguard Investments Ltd v. de Savoye (1990) 3 Supreme Court Reports 1077, 38.

10 The concern regarding outcome determinative choices of forum has been addressed in Australia by means of an ingenious transfer mechanism, which is contained in $a$ legislative scheme for cross-vesting the jurisdiction of Australian courts: Jurisdiction of Courts (CrossVesting) Act, 1987. This

scheme permits a court in $a$ relatively summary fashion to transfer a proceeding to a more appropriate forum within the federation either on motion of a party or on its own motion. The transfer mechanism in

the cross-vesting legislation does much to reduce the frequency of situations of unfairness that can result from permitting greater flexibility in available fora. GRIFFITH, ROSE \& GAGELER, "Further Aspects of the Cross- vesting Scheme•, 62 Australian Law Journal, 1988, 1016. A similar transfer mechanism operates in the United States Federal Court system pursuant to 18 USC $\$ 1404$.

11 A further factor weighing in favour of tolerance is the unusually remedial approach taken to civil litigation in the United States, which is discussed below in the section on •Harmonizing Procedural Law." Under this approach, breaches of the principle of legality are tolerated for the sake of fostering litigation that will enhance standards of liability and operate as a form of market regulation.

12 Tolofson v. Jensen [1994) 3 Supreme Court Reports 1022; John PFeiffer Pty Ltd v. Rogerson

(2000) 172 Australian Law Reports 625.

13 Shevill v. Presse Alliance SA (C6Bl93) [1995) 2 Appeal Cases (Law Reports) 18 (EO.

14 In April 2002, in its PParis/New Delhi Principles on Jurisdiction over Corporations," (available on www.ila-hq.org) the International Law Association proposed that a corporation be subject to the jurisdiction of the courts of a state where "its business, or other professional activity is principally carried on." (emphasis added) It remains to be seen whether this formulation would be acceptable to those who might otherwise insist on "business activities" jurisdiction.

15 The United Nations Convention on Contracts for the International Sale of Goods, 1980 , has been adopted in 61 countries.

16 As is explained on its website, "The Hague Conference is an intergovernmental organization, the purpose of which is 'to work for the progressive unification of the rules of private international law'." http://www.hcch.net/e/index.html

17 Tolofson $v$. Jensen, supra note 12, 169.

18 Smith Kline \& French Labs Ltd v. Bloch (1983] 1 Weekly Law Reports 730, 73334 (CA). See also Piper Aircraft Co v. Reyno 454 US, 235 (1981), where the United States 
Supreme Court listed several reasons why plaintiffs choose American courts.

19 These issues are discussed in the English literature under the rubric "single-forum cases". See L.

COLLINS, et al, Dicey and Morris on the Conflict of Laws (13 ed. 2000), 420-421.

20 Tolofson $v$. Jensen, supra note 12.

21 Morguard $v$. Oe Savoye, supra note 9, 37.

22 WALTER \& BAUMGARTNER, •utility and Feasibility of Transnational Rules of Civil Procedure: Some German and Swiss Reactions to the Hazard-Taruffo Project" 33 Texas International Law journal, 1998,463 at $470-471$.

23 This is suggested by the consensus adoption of Article 33 of the current draft of the proposed Hague Judgments Convention, which would permit the review of excessive damages awards by enforcing courts: Hague Conference on Private International Law, Preliminary Draft Convention on Jurisdiction and Foreign Judgments in Civil and Commercial Matters, as adopted by the Special Commission, October 1999 and revised June 2001, available on http://www.hcch.net/e/workprog/jdgm.html.

24 BORN, -critical Observations on the Draft Transnational Rules of Civil Procedure 33 Texas International Law Journal, 1998, 387.

25 ALIIUNIDROIT Draft Principles and Rules of Transnational Civil Procedure, Introduction - ALI Discussion Draft No. 3, April 8, 2002 and UNIDROIT 2002, Study LXXVI - Doc. 7 (reproduced in the Annex to this issue).

26 Storme (ed.), Approximation of Judiciary law in the European Union, Kluwer (Dordrecht/ Boston/London) 1994.

27 CLERMONT, •jurisdictional Salvation and the Hague Treaty" (1999), 85 Cornell law Review, 89.

28 WALTER \& BAUMGARTNER, supra note 22, 466-467.

29 WALKER, "The Better Part of Harmonizing Jurisdictional Law", 2002 Proceedings of the

American Society of International Law (forthcoming).

30 Which is well understood by Europeans who have pioneered the techniques of progressive integration, including harmonization of legal standards. 